\title{
THE EFFECTS OF SUN RADIATION ON THE QUALITY OF SACHET AND BOTTLED WATER
}

\author{
Onosakponome, Ogaga Robert \\ Department of civil engineering, Federal University of Technology, \\ Owerri, Imo State, Nigeria
}

\begin{abstract}
In recent times, packaging of potable water in form of bottled water or sachet water has gradually gained wider acceptability in our major cities. Demographic and socioeconomic variables are largely responsible for the choice and preference for this product. Packaged water exposed to the hot sun in the process of storage or transportation does cause serious chemical exposure. Ultraviolet rays from the sun or high temperatures do accelerate leaching of toxic substance (dioxin) and other plastic chemicals into the water. The polythene bags also develop germs and micro-organisms which enter the water through the deterioration of the polythene bag (weather susceptible). Two bags of sachet water $(60 \mathrm{cl})$ and two packs of bottled water $(75 \mathrm{cl})$ each were selected for the sample from three purposely selected water packaging companies with regard to the rate of production and consumption. These samples were exposed to direct heat of sunlight to achieve sun radiation, a control was obtained from the same source and assessed after the exposed sample has been tested at intervals of 1 week, 2 weeks, 3 weeks, 4 weeks, 2 months, and finally 3 months duration. The parameter analysis conducted was in adherence to WHO standards and criteria. The results obtained shows that the concentration levels of various physiochemical parameters in the studied packaged water types did not exceed the international guidelines for drinking water but variations of physiochemical properties were found when compared with the control. Such variation can be attributed to the leaching of the compounds produced from the photodegradation of Polyethylene terephthalate (PET) by sunlight. Due to the presence of organic and inorganic compounds in the water sample, residual chlorine, for all samples underwent a depleting process during the course of exposure; Company A recorded a value ranging from 0.02-0.21 mg/l, while Company B's values ranged from of $0.03-0.2 \mathrm{mg} / \mathrm{l}$ and Company C maintained $0.05 \mathrm{mg} / \mathrm{l}$ to $0.23 \mathrm{mg} / \mathrm{l}$. The result obtained for colour slightly increased, a slight variation was experienced in the $\mathrm{pH}$ of samples analysed during exposure, the values
\end{abstract}

ranged from 6.9-7.2 for Company $A$, while Company B maintained a pH of 7 and Company $\mathrm{C}$ a pH range of 7-7.4, averaging 7.05, 7 and 7.2 respectively, while the taste and odour deteriorated with time (sachet water; after the first week of exposure while bottled water varied after the fourth week) giving off a relative polymeric assessment. The storage of packaged water in condition above $35^{\circ} \mathrm{C}$ or exposure to sunlight leads to acceleration of organic and inorganic compounds leaching from the packaging material to the content water especially that of sachet water. The study has shown that storage conditions of sachet water products present varying bacteriological qualities. Sachet water products when exposed to sunlight deteriorate faster than refrigerated ones due to solar radiation effect.

KEYWORDS: Sachet water, Bottled water, Leaching, Sunlight, Concentrations, Exposure.

\section{INTRODUCTION}

Potable water is an integral component and indispensable requirement in life. It therefore cannot be substituted for any other fluid. It can be sourced from surface water such as rivers, streams and ground water sources like spring, well water and borehole water. Water as a universal solvent has the capability to dissolve many substances including organic and inorganic compounds. This outstanding property of water can be ascertained to the inconceivability to take in water in its pure form [3]. The quality of water generally refers to the component of water present at the optimum level for suitable growth of plants and animals. The maximum productivity can be obtained only when the physical and chemical parameters are present at optimum level. Water for human consumption must be free from organisms and chemical substances and such large concentrations may affect health [23].

The non-availability of good quality drinking water has resulted into a number of health challenges as water is known to be a primary causative agent of 


\section{International Journal of Engineering Applied Sciences and Technology, 2021 \\ Vol. 6, Issue 2, ISSN No. 2455-2143, Pages 192-208 \\ Published Online June 2021 in IJEAST (http://www.ijeast.com)}

many contagious diseases. In developing countries of the world, $80 \%$ of all diseases and over $30 \%$ of deaths are related to drinking water [18]; [17]. Research have shown that when clean water and needed hygiene condition are provided, the chances of occurrence of diarrhoea, sleeping sickness and guinea worm infestation can be eliminated or prevented by 50,80 and 100 percent respectively [1]. Insufficiency of water supply has given rise to the involvement of private individuals in the production of packaged drinking water (pure water) [7]. Packaged drinking water (PW) sold in bottles and plastic bags/sachets is widely consumed; the scale of packaged water consumed is substantial: In 2011, documented global bottled water (1500ml) sales exceeded 225 billion litres [21] while statistics on sales of packaged sachet water (PSW, drinking water packaged in sealed plastic sleeves, typically $500 \mathrm{ml}$ ) are more difficult to obtain. Commonly, sachet water is known to be a safe and instant means of quenching public thirst. Sachet water is usually consumed without further processing especially during the dry and hot seasons in Nigeria. The hygiene of the environment and conditions under which majority of brands of packaged water are produced and stored are faced with a number of uncertainties. Therefore constant and periodic assessment of packaged drinking water is needed to satisfactorily enlighten the consumers about quality [1]; [5].

National and international organizations standards have been explicitly developed for safe drinking water quality. Virtually all the available standards have upper limits for physical, chemical and microbiological properties which when exceeded are dangerous and have the potential of been harmful to the end users. A number of studies have been carried out on the quality assessment of sachet and bottled drinking water across different Nigerian towns/cities and some part of the world. Nearly in all these studies reported across the country and some part of the world, the quality of approximately $50 \%$ drinking water available to the populace seems to be unfit for consumption. It is however not out of place to assume that similar situation can be obtainable in other Nigerian cities or towns [14].

The quality of water may vary from one source to another based on several parameters such as water sources, type of water purification, and storage tanks [13]. The quality and physicochemical properties of packaged water have been study extensively in many countries, for examples in Canada [19] and USA [2]. Polyethylene terephthalate (PET) is the material most commonly used to make the clear plastic bottles in which bottled water is sold and polyethylene water sachet
(PWS) popularly called "Pure Water" Nylon. The contents of the PET bottle, and the temperature at which it is stored, both appear to influence the rate and magnitude of leaching of organic and inorganic compounds from PET bottle [20]. Several studies have shown the presence of compounds in bottled water, in non-negligible concentrations. Mutsuga and others [15] reported the acetaldehyde forming during the polymerization reaction and the hot step process in the bottle water manufacture. Cristina Bach and others [26] tested water bottles after exposure to extreme conditions of high temperature and ultraviolet (UV) radiation to accelerate the possible migration of substances. Temperatures in regions that exceed $45^{\circ} \mathrm{C}$ at the summer time and the storing of bottled water in the car or out in the open market is a very common practice. Therefore, it is necessary to conduct the effect of temperature on the physicochemical properties of the bottled water. On the other hand, it is quite often for people to use the plastic bottled water outdoor and some markets leave it under direct sunlight. Therefore, understanding the effects of sunlight on the quality of bottled water is imperative.

\section{PRODUCTION OF PLASTIC BAGGED DRINKING WATER}

Tap water is collected into a reservoir and is treated with chlorine tablet. The water is then pumped into an overhead tank through four sets of filters with pore sizes of 5 microns each. The water descends or flows with force into four other sets of filters, two with pore size of 1 micron and the other two with pore size of 0.5 micron. The water then passes through carbon into a stainless steel ultraviolet machine before finally passing through a packaging machine where it is automatically packed into sachets $(500 \mathrm{ml})$. In-built in the machine is an ultraviolet light that casts on the roll of the rubber for packaging. The bags used for packaging factory produced plastic bag drinking water are made of high-density polyethylene (HDPE), which is very strong and has higher tensile strength difficult to elongate, and can withstand higher temperatures.

\section{BRIEF CONCEPT OF SACHET WATER}

Sachet water, viewed as the latest, low-cost technological incarnation of vended water in developing cities has allowed a steady evolvement of vended water. It has been noted through the review of literature that sachet drinking water is now prevalent in countries contiguous to Nigeria, Ghana, Cote d'Ivoire, Burkina Faso, Togo, Benin, Niger and Cameroon. A recent body of literature highlights the challenges in maintaining quality control of machine vended water (i.e. filling personal containers) in the US and Europe [4]; [10]; 


\section{International Journal of Engineering Applied Sciences and Technology, 2021 \\ Vol. 6, Issue 2, ISSN No. 2455-2143, Pages 192-208 \\ Published Online June 2021 in IJEAST (http://www.ijeast.com)}

[12], [22]. Sachet drinking water has been important for low income households by eliminating the need for unsafe water storage vessels. The deterioration of water quality during transport and storage is well established in public health literature [6]; [9]; [25]. The determination of the microbiological quality of water is essential in testing for the overall quality of water, which often involves the enumeration of bacteria of faecal origin [11]. The contamination of water with infected faecal material is common in areas with poor standards of hygiene and sanitation [27].

\section{BOTTLED WATER}

There is still no clarity on the reason for the increase of consumption of bottled water and surveys conducted indicate different reasons for choosing bottled water over tap water. The drinking habits of consumers are also diverse and depend on environmental and economic factors [16]. Demographic variables can somehow influence bottled water usage and these variables include ethnic group, age, income, occupation and gender [8]. Consumers perceive tap water to have more negative impact on their health due to the use of chemicals during its production than bottled water. Hence, the use of bottled water is seen as a way of healthy living. This has resulted in consumers being exposed to different hazards. The biggest challenge facing the bottled water industry is the assigning of a realistic shelf-life given these bottled water. It is known that some of these bottled water were not chemically treated before consumption.

\section{WATER SAMPLING AND EXPERIMENTAL DETERMINATION OF PARAMETERS}

Two bags of sachet water $(60 \mathrm{cl})$ and two packs of bottled water $(75 \mathrm{cl})$ each were selected for the sample from three purposively selected water packaging companies with regard to the rate of product consumption by the residents of FUTO community. These samples were exposed to direct heat of sunlight to achieve sun radiation; a control was obtained from the same source and assessed after the exposed sample has been tested at intervals of 1 week, 2 weeks, 3 weeks, 4weeks, 2 months, and finally 3 months duration.
Plate 3.1: Location of exposure

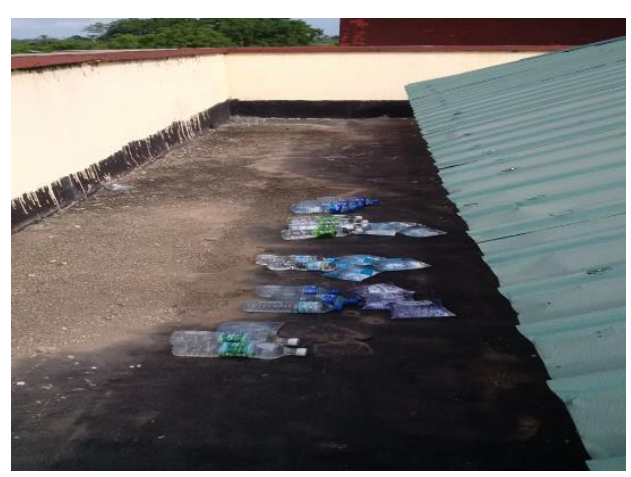

Physico-Chemical analysis The parameter analysis conducted was in adherence to WHO (World Health Organization) standards and criteria [24].

A. Determination of $\mathbf{p H}$ : The $\mathrm{pH}$ of water samples was determined by a HANNA HI 83200 multi-parameter bench photometer of range 6.5 to $8.5 \mathrm{pH}$ and a resolution of $0.1 \mathrm{pH}$ based on the adaptation of the Phenol Red method. The reaction with the HI 93710-0 reagent causes a yellow to red tint in the sample.

Procedures - The photometer was first zeroed, using the unreacted sample in the $10 \mathrm{ml}$ cuvette (up to the mark). The cuvette was removed and 5 drops of $\mathrm{HI}$ 93710-0 Phenol Red Indicator and mix the solution. The measurement was carried out by reinserting the cuvette into the instrument and the $\mathrm{pH}$ value obtained. $\mathrm{pH}$ indicators was also used to measure the $\mathrm{pH}$, by making use of the fact that their colour changes with $\mathrm{pH}$. Visual comparison of the colour of a test solution with standard colour chat will provide a means to measure $\mathrm{pH}$ accurate to the nearest whole number.

B. Determination of Colour: The colour of water samples was determined by a HANNA HI 83200 multi-parameter bench photometer of range 0 to $500 \mathrm{PCU}$ (Platinum Cobalt Units) and a resolution of 1 PCU based on the adaptation of standard methods for the examination of water and wastewater $18^{\text {th }}$ edition, Colorimetric Platinum Cobalt method.

Procedure: The photometer was first zeroed, using deionized water in the $10 \mathrm{ml}$ cuvette. Another $10 \mathrm{ml}$ cell was filled up to the mark with unfiltered sample and measure; we obtained the apparent colour. We will filter $10 \mathrm{ml}$ of the sample through 
a filter with a $0.45 \mu \mathrm{m}$ membrane into the third cuvette, up to the $10 \mathrm{ml}$ mark and measure the true colour.

C. Determination of Temperature: Cool water is generally more palatable than warm water, and temperature will impact on the acceptability of a number of other inorganic constituents and chemical contaminants that may affect taste. High water temperature will enhance the growth of microorganisms and may increase taste, odour, colour and corrosion problems. The value for this parameter was obtained using a pocket thermometer of range $20^{\circ} \mathrm{C}$ to $100^{\circ} \mathrm{C}$.

D. Determining Odour and Taste: These parameters were analysed based on the organoleptic assessment of water.

E. Determination of Residual Chlorine: Residue chlorine $=$ Total Chlorine - Free Chlorine. We determined the value of free chlorine and subtract it from that of total chlorine.

i. Total Chlorine: Total chlorine was determined by a HANNA HI 83200 multi-parameter bench photometer at the range of 0.00 to $3.50 \mathrm{mg} / \mathrm{l}$ and a resolution of $0.01 \mathrm{mg} / \mathrm{l}$. This analysis was based on adaptation of the EPA DPD method 330.5. The reagent we used is a packet of a HI 93711-0 DPD powder reagent for each sample tested. The reaction between the chlorine and DPD reagent caused a pink tint in the sample.

Procedure - The photometer was first zeroed, using the unreacted sample in the $10 \mathrm{ml}$ cuvette. We add one packet of HI 93711 DPD reagent and shake gently for 20 seconds before taking our reading and the result was recorded in $\mathrm{mg} / \mathrm{l}$ of total chlorine.

ii. Free Chlorine: Free chlorine was determined by a HANNA HI 83200 multi-parameter bench photometer at a range of 0.00 to $2.50 \mathrm{mg} / \mathrm{l}$ and a resolution of $0.01 \mathrm{mg} / 1$. This analysis will be based on adaptation of the EPA DPD method 330.5. The reagent we used is a packet of a HI 93701-0 DPD powder reagent for each sample tested. The reaction between the chlorine and DPD reagent caused a pink tint in the sample.

Procedure: The photometer was first zeroed, using the unreacted sample in the $10 \mathrm{ml}$ cuvette. We added one packet of HI 93701 DPD reagent and shaked gently for 20 seconds before taking our reading and the result was recorded in $\mathrm{mg} / \mathrm{l}$ of free chlorine.

\section{Bacteriological Examination of Water: Total Plate Count}

Bacteria found in water have different optimum temperatures and if an organism grows at $37^{\circ} \mathrm{c}$, it is likely to be pathogenic bacterium from the soil and sewage. Those that grow at $22^{\circ} \mathrm{c}$ are natural water bacteria. A plate count is therefore useful in detecting any form of contamination. It gives an estimate of the general hygienic or sanitary quality of water and in particular, an indication that pollution is taking place. The method employed is briefly as follows; A measured volume of water is serially diluted into a $1 / 10,1 / 100,1 / 1000$ up to $1 / 1000$, 000 from each dilution tube is plated in nutrient agar and incubated at $37^{\circ} \mathrm{c}$ for 24 hours and the resulting colonies counted. The number of colonies in a known volume of water is thus determined. 
International Journal of Engineering Applied Sciences and Technology, 2021

Vol. 6, Issue 2, ISSN No. 2455-2143, Pages 192-208

Published Online June 2021 in IJEAST (http://www.ijeast.com)
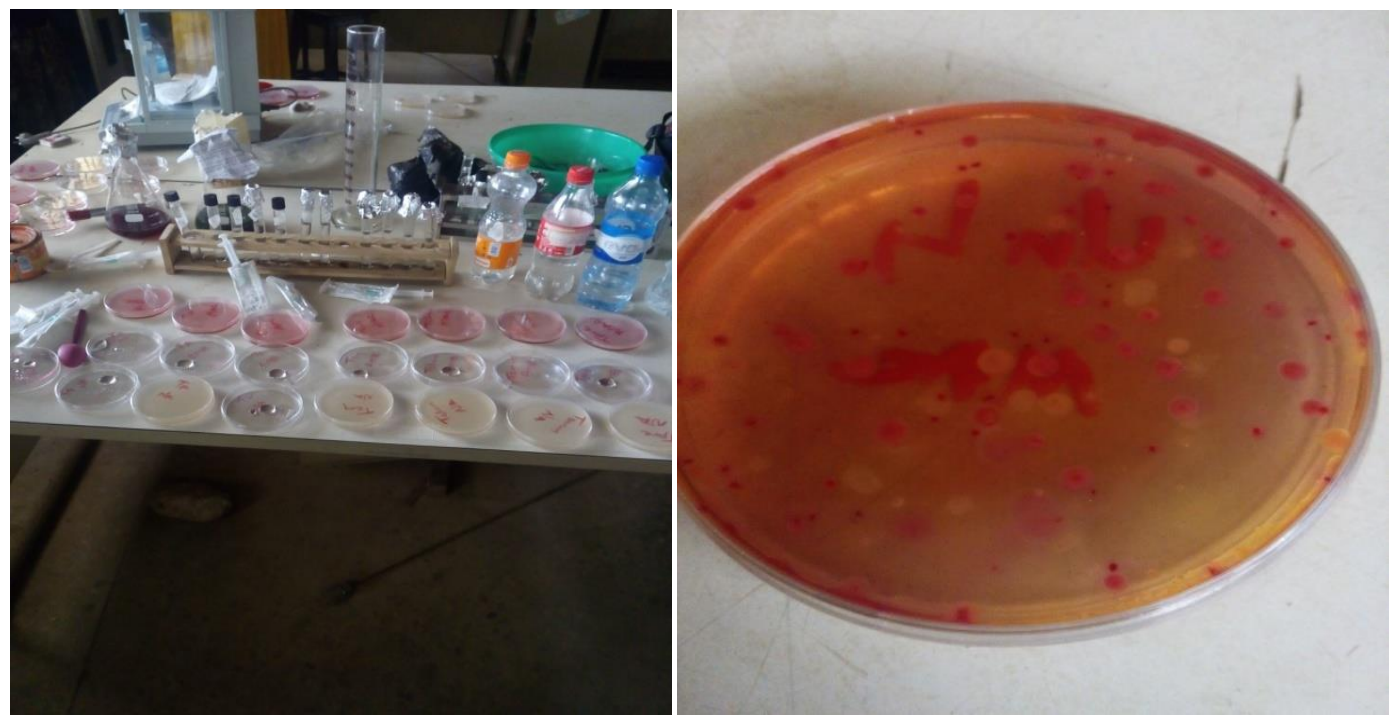

Plate 3.2: Water analysis using sub culturing for the bacteriological analysis

IV. RESULTS

\section{Physico-chemical Analysis Results}

The measurement of physicochemical properties of samples has been carried out at intervals of one week, two weeks, three weeks, one month, two months and the third month; after exposing bottled water under natural sunlight to achieve radiation. The results clearly indicate a variation in each physicochemical parameter with increasing of sunlight exposure time.

\section{pH Analysis}

$\mathrm{pH}$ is one of the parameters that addresses the aesthetic quality of water such as taste which has no serious health significance [24]. As an important operational water quality determinant, the closer $\mathrm{pH}$ gets to 1 , the more acidic the water becomes.

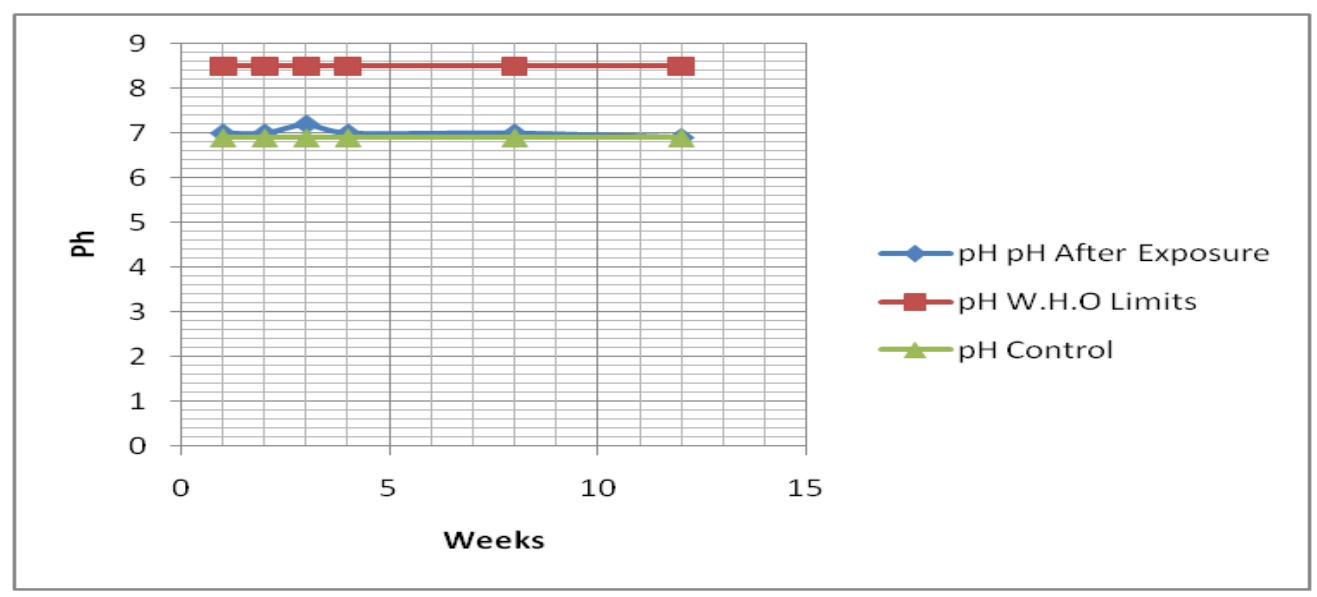

Figure 4.1a: pH Analysis Result on sachet water for company A. 
Published Online June 2021 in IJEAST (http://www.ijeast.com)

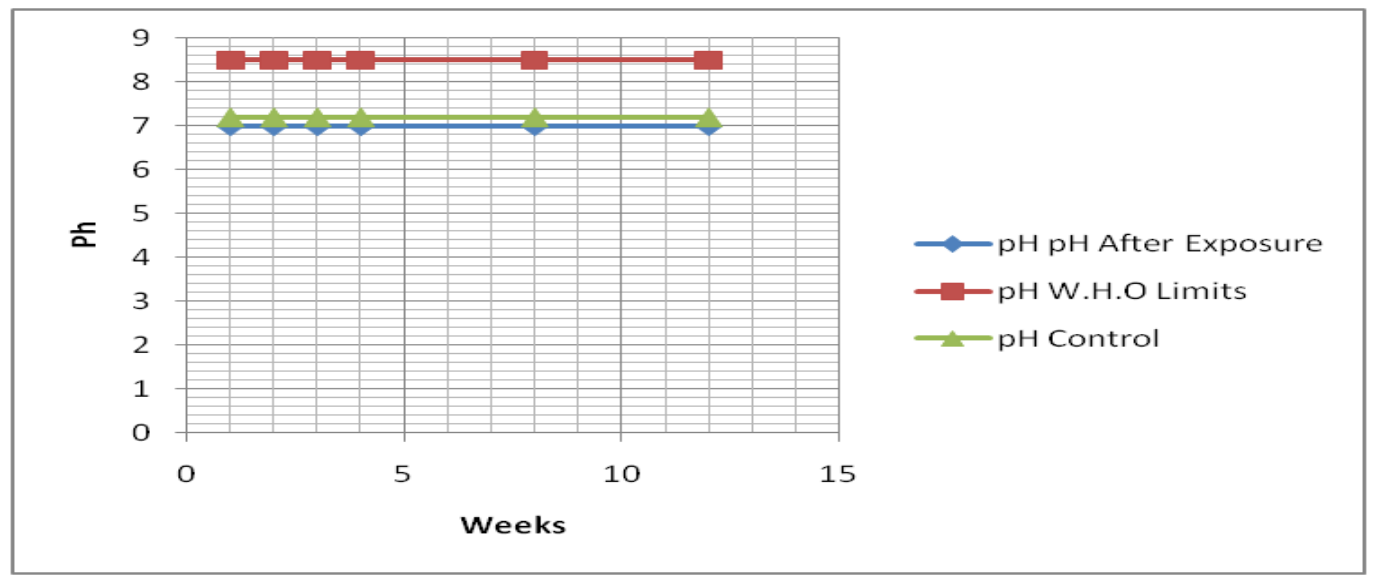

Figure 4.1b: pH Analysis Result on sachet water for company B.

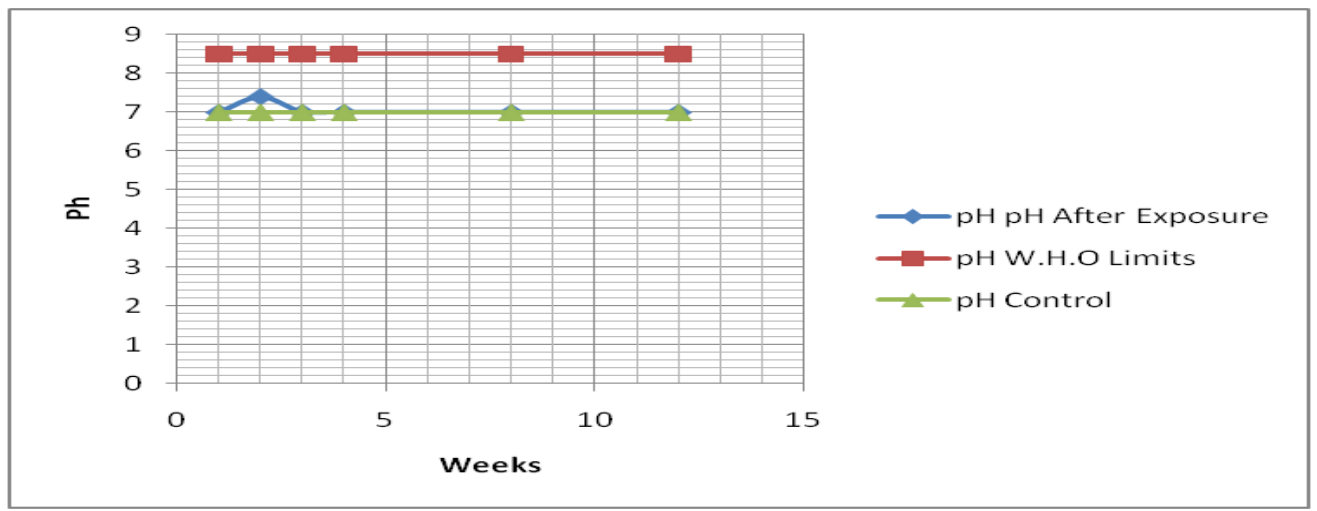

Figure 4.1c: pH Analysis Result on sachet water for company C.

The $\mathrm{pH}$ of sachet water before storage was 6.9, 7.2 and 7for Company A, B and C brands respectively and during exposure $\mathrm{pH}$ values ranged from 6.9-7.2 for Company A, while Company B maintained a $\mathrm{pH}$ of 7 and Company $\mathrm{C}$ a pH range of 7-7.4, averaging 7.05, 7 and 7.2 respectively. It was observed that those stored in the sun usually record slight increase in $\mathrm{pH}$ compared with those stored at room temperature and in the refrigerator and generally $\mathrm{pH}$ varied throughout the study period. International standards for drinking water suggest that $\mathrm{pH}$ less than 6.5 or greater than 9.2 would impair the potability of the water. Figure 4.1a to c shows a visible variation in the $\mathrm{pH}$ level on the third and second week of exposure respectively. Figure 4.1d maintained uniform values during the period of study, when compared to W.H.O standard limit and control; it was observed that $\mathrm{pH}$ vary with the control but falls within the W.H.O standard.

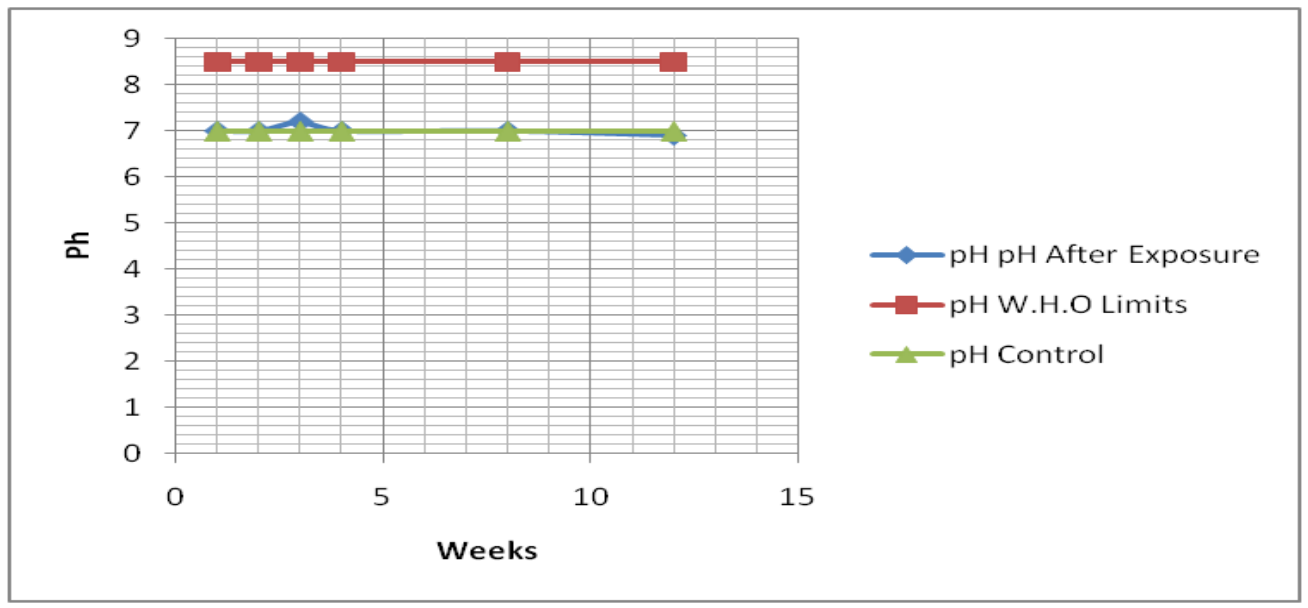

Figure 4.1d: pH Analysis Result on bottled water for company A. 
International Journal of Engineering Applied Sciences and Technology, 2021

Vol. 6, Issue 2, ISSN No. 2455-2143, Pages 192-208

Published Online June 2021 in IJEAST (http://www.ijeast.com)

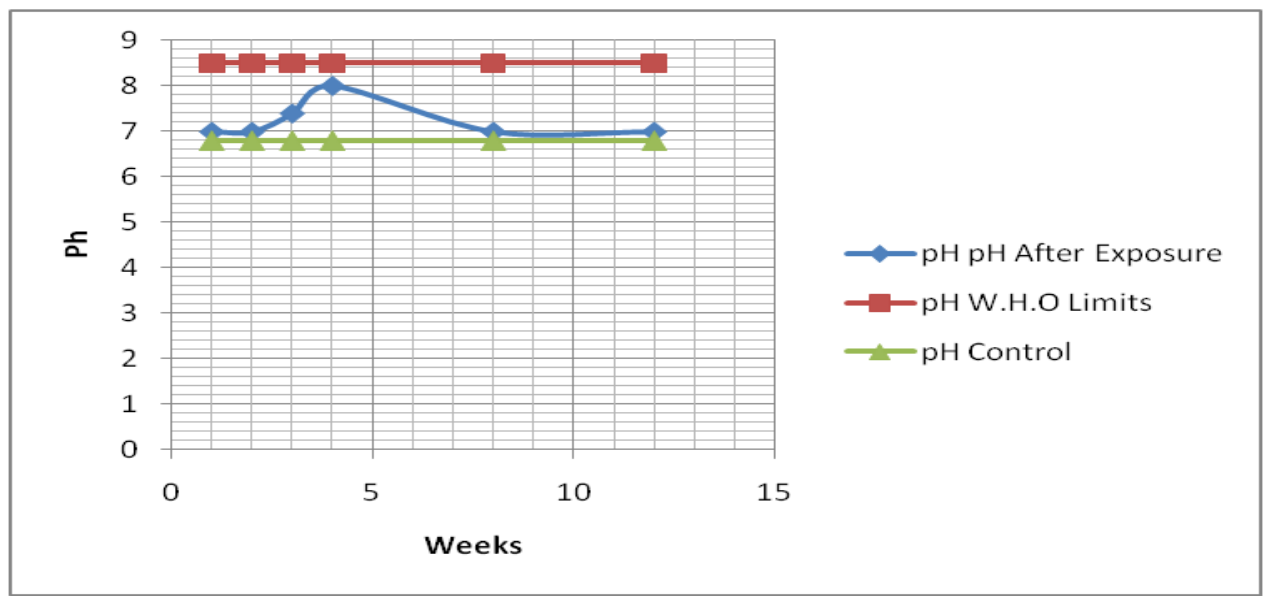

Figure 4.1e: pH Analysis Result on bottled water for company $B$.

The $\mathrm{pH}$ of bottled water before storage was 7, 6.8 and 7.1 for Company A, B and C brands respectively; all fall within acceptable standards and during exposure $\mathrm{pH}$ values ranged from 6.9-7.2 for Company A, while Company B's $\mathrm{pH}$ values ranged from of 7-8 and Company $\mathrm{C}$ has a $\mathrm{pH}$ value of 7 , averaging 7, 7.5 and 7 respectively, there is a slight increment compared to the control due to exposure; generally $\mathrm{pH}$ varied throughout the study period. Figure 4.1d shows a visible variation in the $\mathrm{pH}$ level on the third week of exposure while in Figure 4.1e there is a sharp increase in the $\mathrm{pH}$ value on the third and fourth week from 7-8 showing a visible effect of sun radiation on the exposed sample when compared with the control.

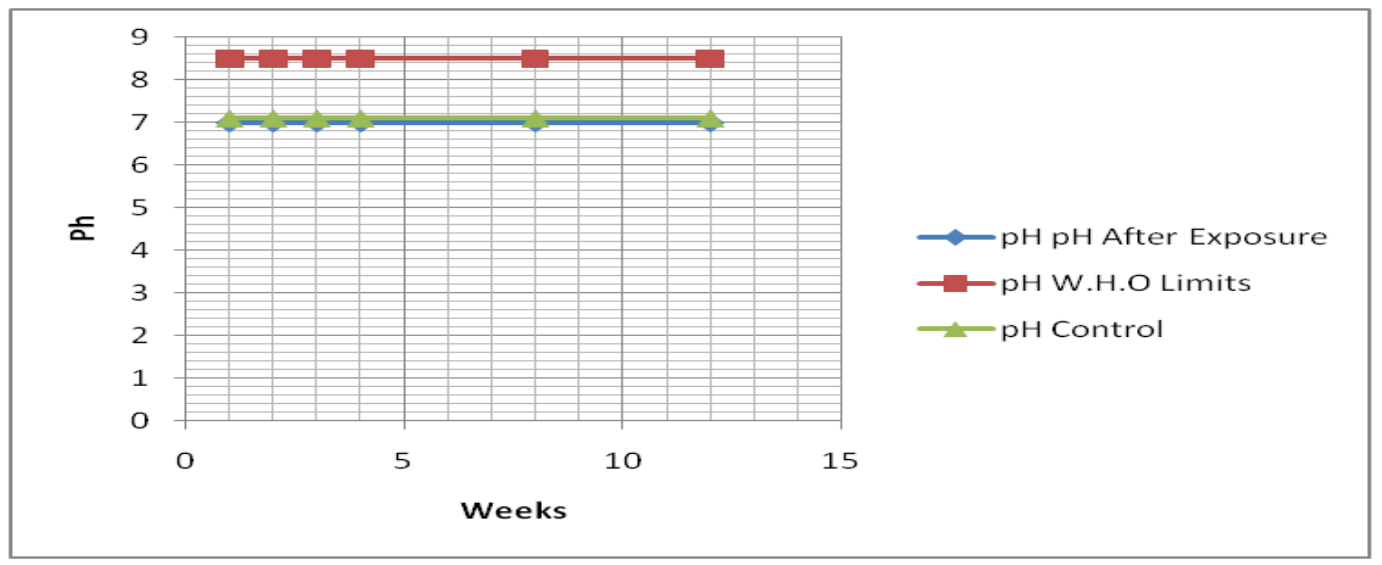

Figure 4.1f: pH Analysis Result on bottled water for company C.

\section{Residual Chlorine}

The presence of residual chlorine (free chlorine) in drinking water indicates that a sufficient amount of chlorine was added initially to the water to inactivate the bacteria and some viruses that cause diarrheal disease and the water is protected from recontamination during storage. The presence of residual chlorine in drinking water is correlated with the absence of most disease causing organisms and thus a measure of the potability of water. 
International Journal of Engineering Applied Sciences and Technology, 2021

Vol. 6, Issue 2, ISSN No. 2455-2143, Pages 192-208

Published Online June 2021 in IJEAST (http://www.ijeast.com)

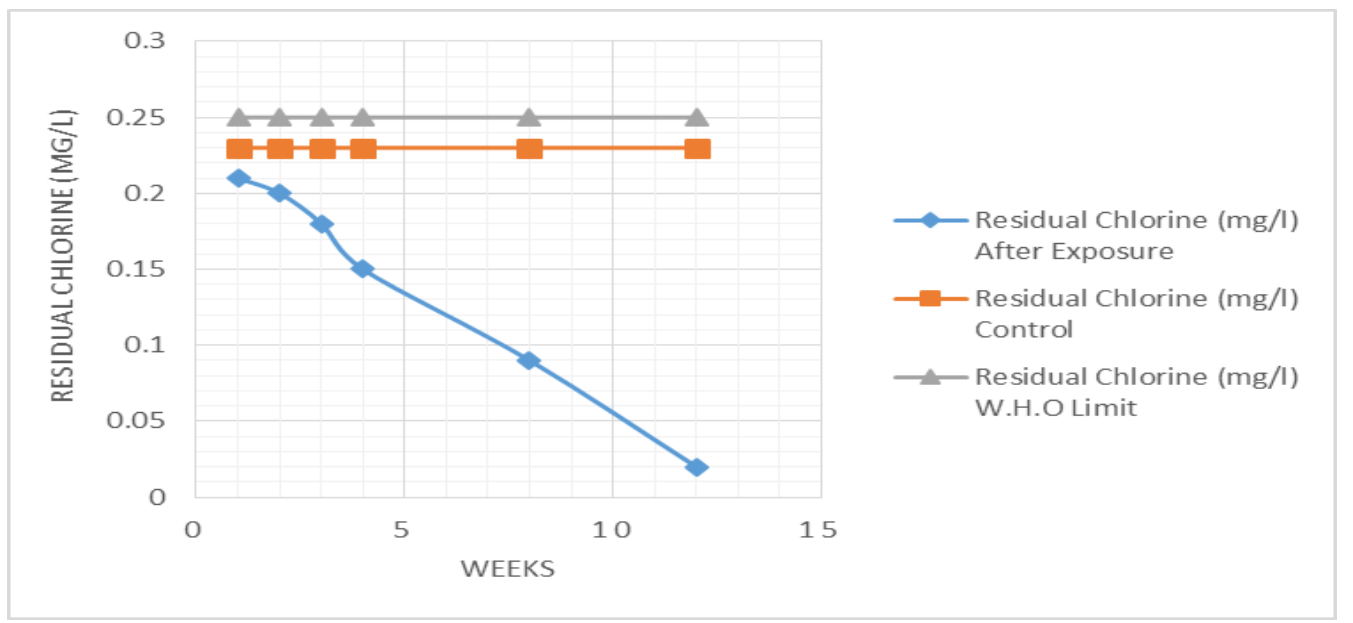

Figure 4.2a: Residual Chlorine Analysis Result on sachet water for company A.

Residual Chlorine in the control of sachet water was $0.23,0.21$ and 0.23 for Company A, B and C brands respectively; all samples experienced a drastic change during the course of exposure; Company A recorded a value ranging from $0.02-0.21 \mathrm{mg} / 1$, while Company B's values ranged from of $0.03-0.2 \mathrm{mg} / \mathrm{l}$ and Company $\mathrm{C}$ maintained $0.05 \mathrm{mg} / 1$ to $0.23 \mathrm{mg} / \mathrm{l}$, Figure $4.2 \mathrm{a}-\mathrm{c}$ shows a sharp drop in the residual chlorine content of the sample especially on the fourth week (one month)and eight week (two months) of exposure and this is uniform for the three brands.

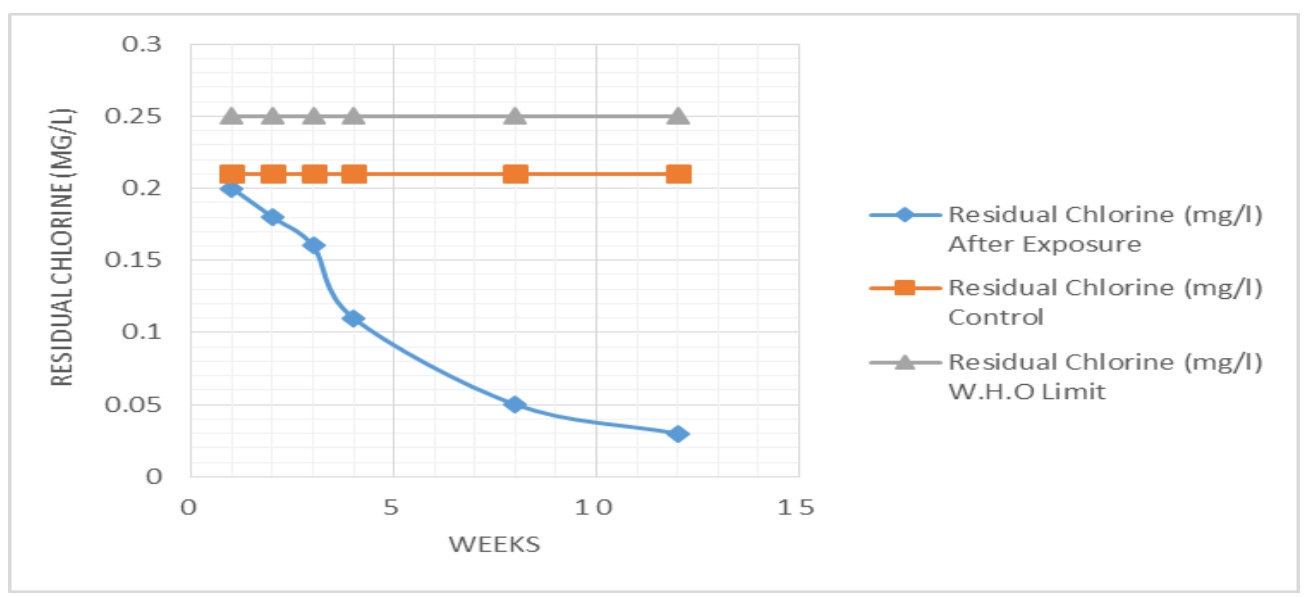

Figure 4.2b: Residual Chlorine Analysis Result on sachet water for company B. 
International Journal of Engineering Applied Sciences and Technology, 2021

Vol. 6, Issue 2, ISSN No. 2455-2143, Pages 192-208

Published Online June 2021 in IJEAST (http://www.ijeast.com)

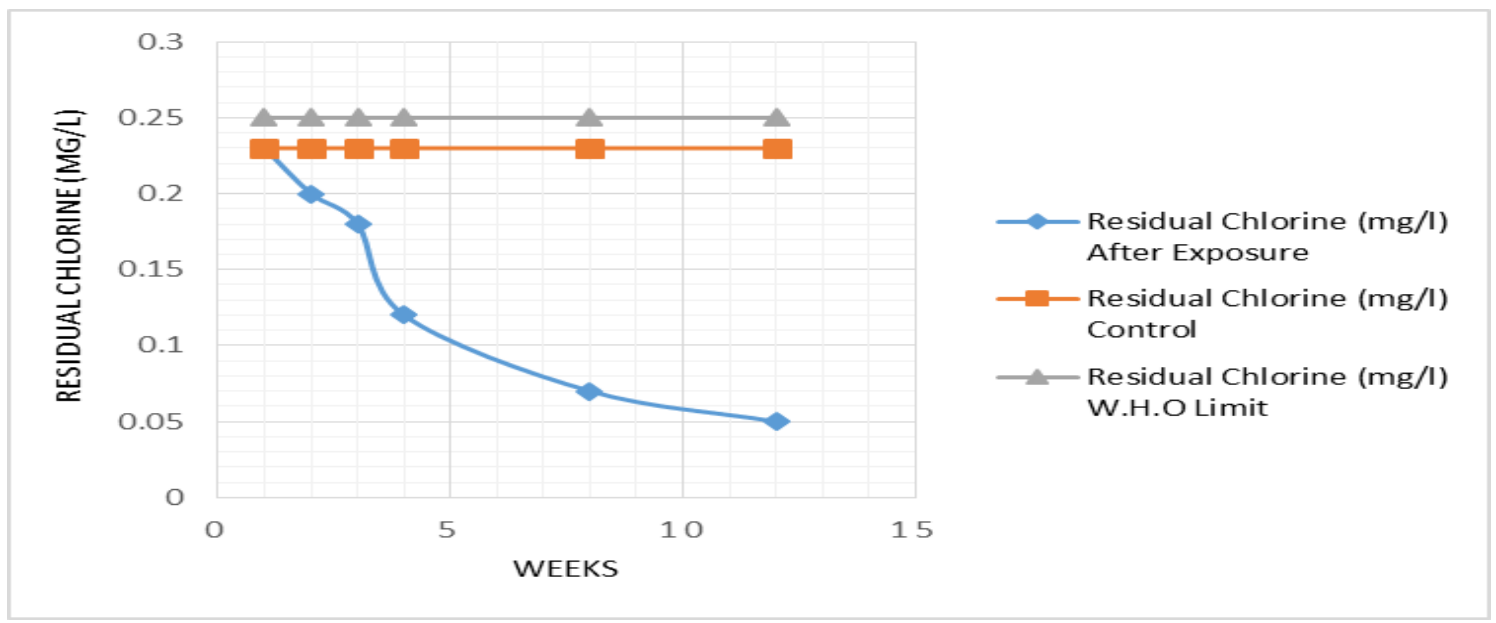

Figure 4.2c: Residual Chlorine Analysis Result on sachet water for company C.

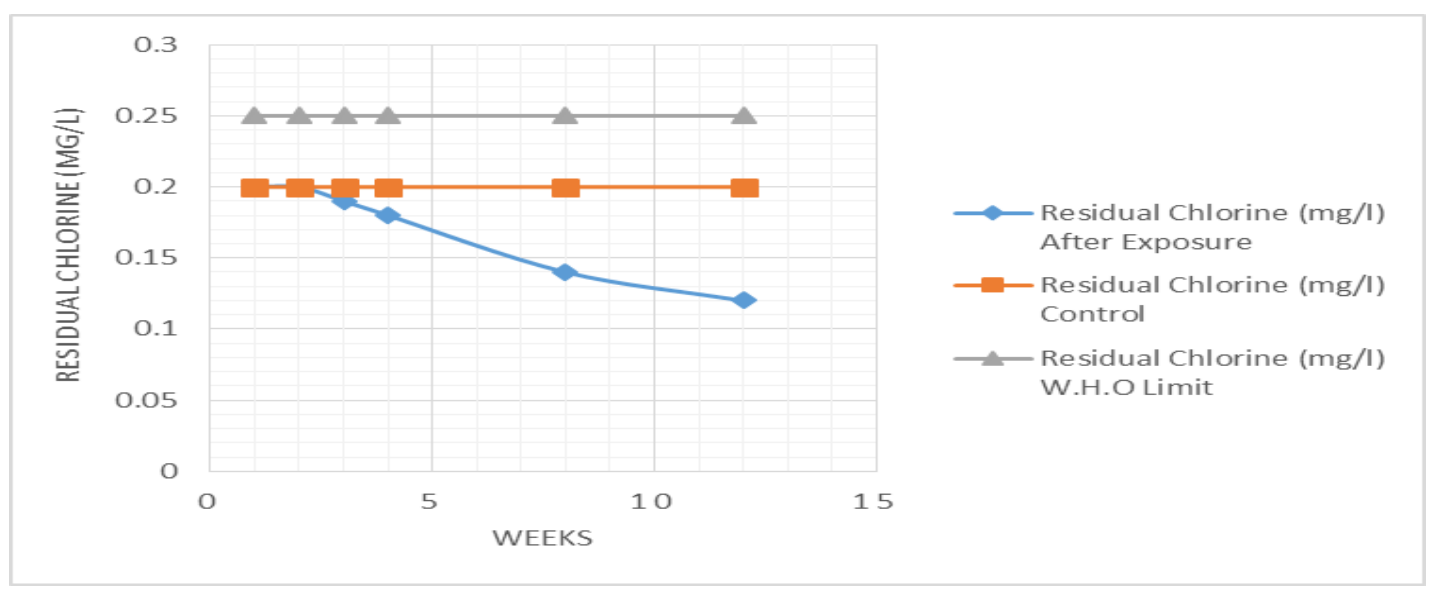

Figure 4.2d: Residual Chlorine Analysis Result on bottled water for company A.

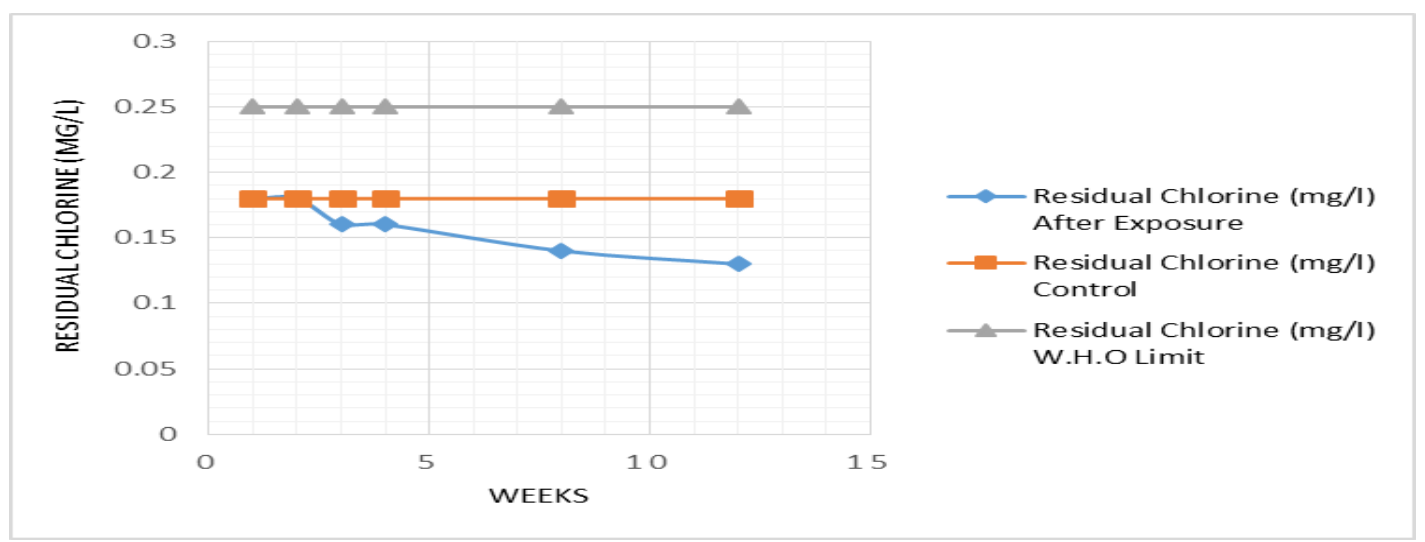

Figure 4.2e: Residual Chlorine Analysis Result on bottled water for company B. 
International Journal of Engineering Applied Sciences and Technology, 2021

Vol. 6, Issue 2, ISSN No. 2455-2143, Pages 192-208

Published Online June 2021 in IJEAST (http://www.ijeast.com)

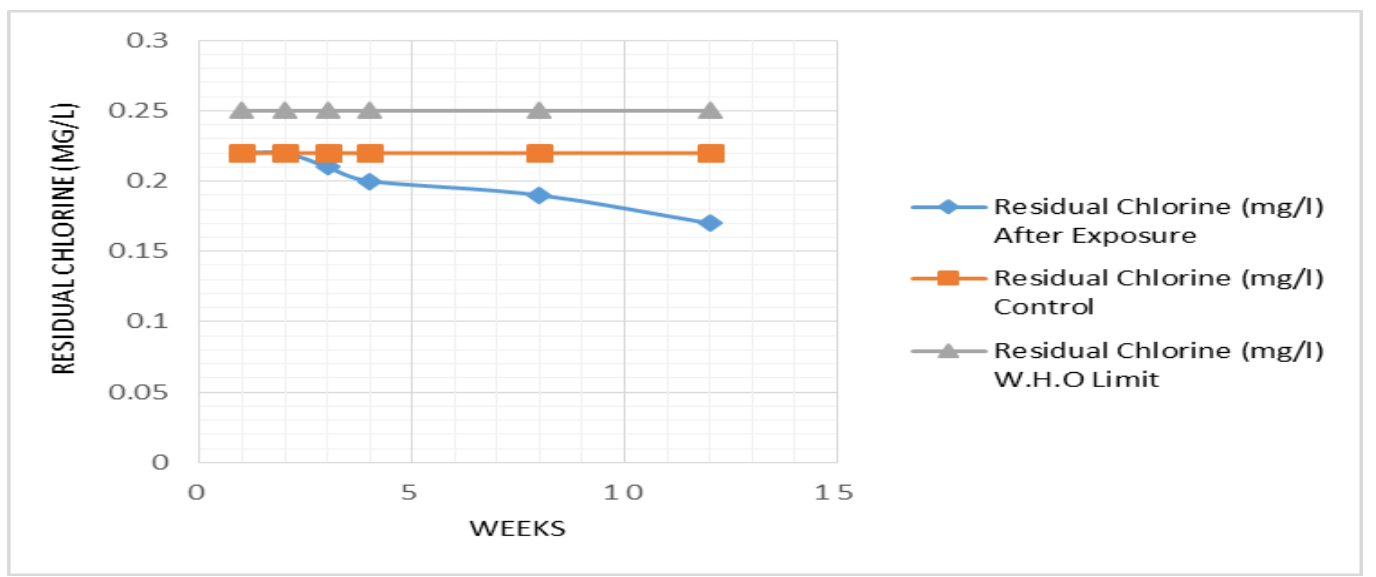

Figure 4.2f: Residual Chlorine Analysis Result on bottled water for company C.

After production of bottled water a residual chlorine value of $0.2,0.18$ and 0.22 was recorded for Company A, B and $\mathrm{C}$ brands respectively; after duration of exposure; Company A recorded a value ranging from 0.12-0.20 $\mathrm{mg} / \mathrm{l}$, while Company B's values ranged from of $0.13-0.18 \mathrm{mg} / \mathrm{l}$ and Company $\mathrm{C}$ displayed a $0.05 \mathrm{mg} / \mathrm{l}$ to 0.23 $\mathrm{mg} / \mathrm{l}$ range of value, Figure $4.2 \mathrm{~d}-\mathrm{f}$ shows a drop in the residual chlorine value across the brands from the three companies. Comparing Figure 4.2 a-c to Figure 4.2 d-f we can conclude that sun radiation has more depleting effect on the residual chlorine in sachet water than in bottled water, they are used up when they react with inorganic and organic materials and metals found in the water sample as a result of leaching.

\section{Colour}

Drinking Water should ideally have no visible colour. Most consumers can detect colour above 15 PCU in a glass of water or non-coloured bottled water containers. According to W.H.O levels of colour below 15 PCU are usually acceptable to consumers, but acceptability may vary. Unit for colour measurement (platinum cobalt unit) is based on platinum cobalt scale.

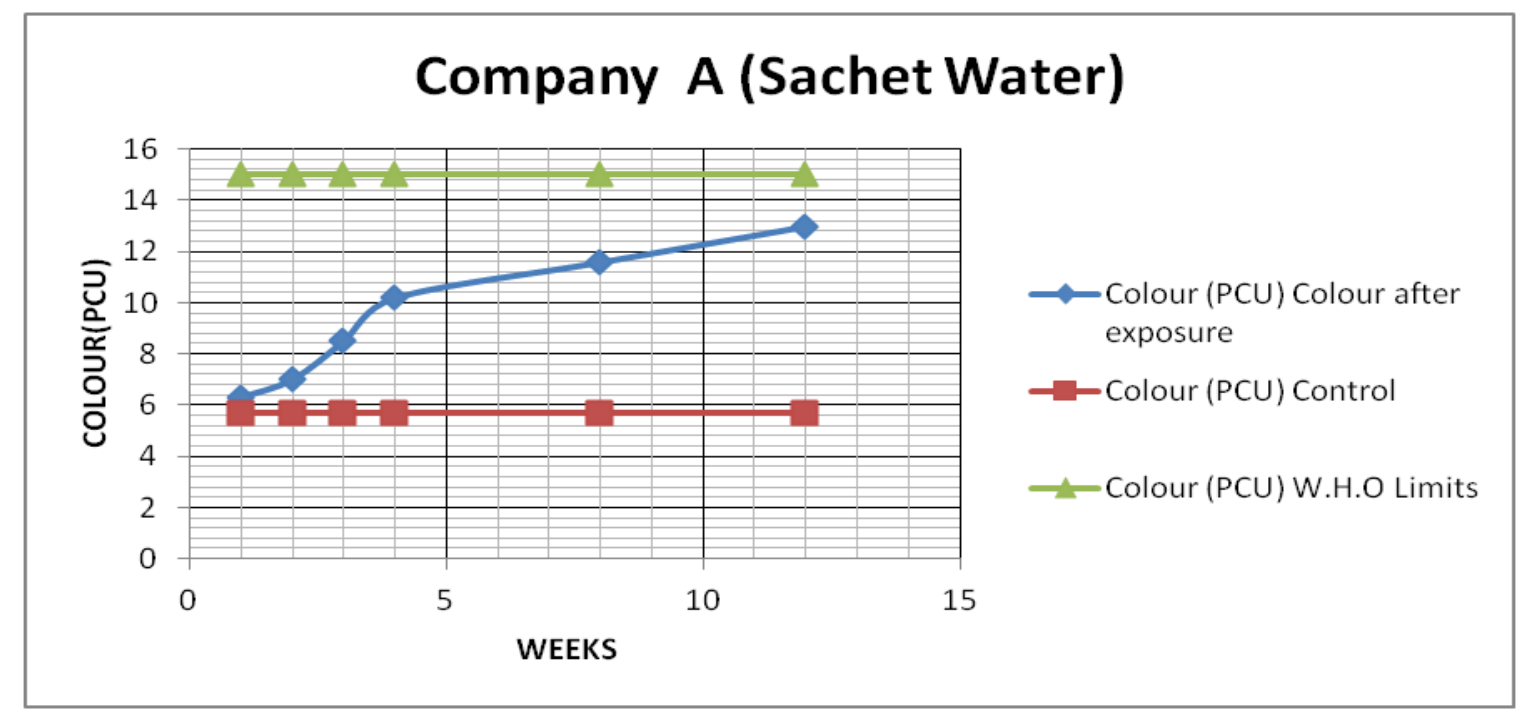

(PCU) - Platinum Cobalt Unit

Figure 4.3a: Colour Analysis Result on sachet water for company A. 
International Journal of Engineering Applied Sciences and Technology, 2021

Vol. 6, Issue 2, ISSN No. 2455-2143, Pages 192-208

Published Online June 2021 in IJEAST (http://www.ijeast.com)

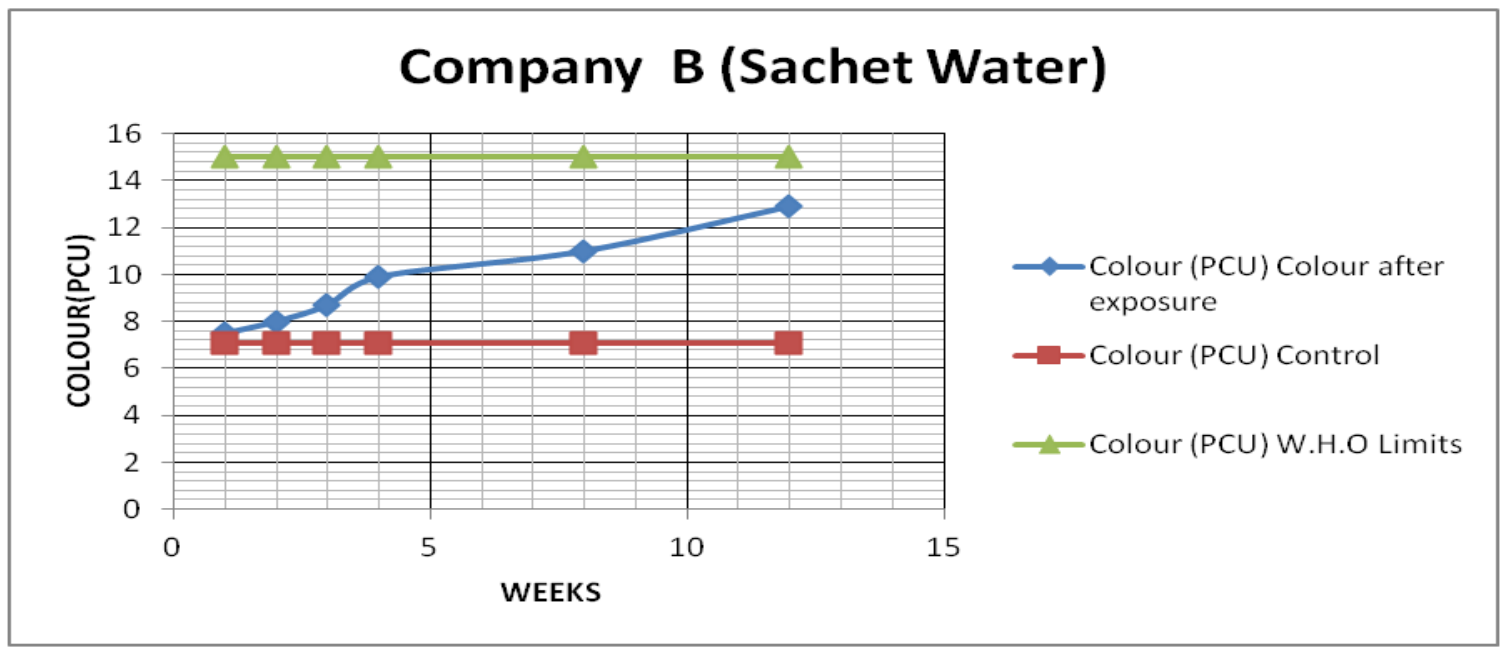

Figure 4.3b: Colour Analysis Result on sachet water for company B.

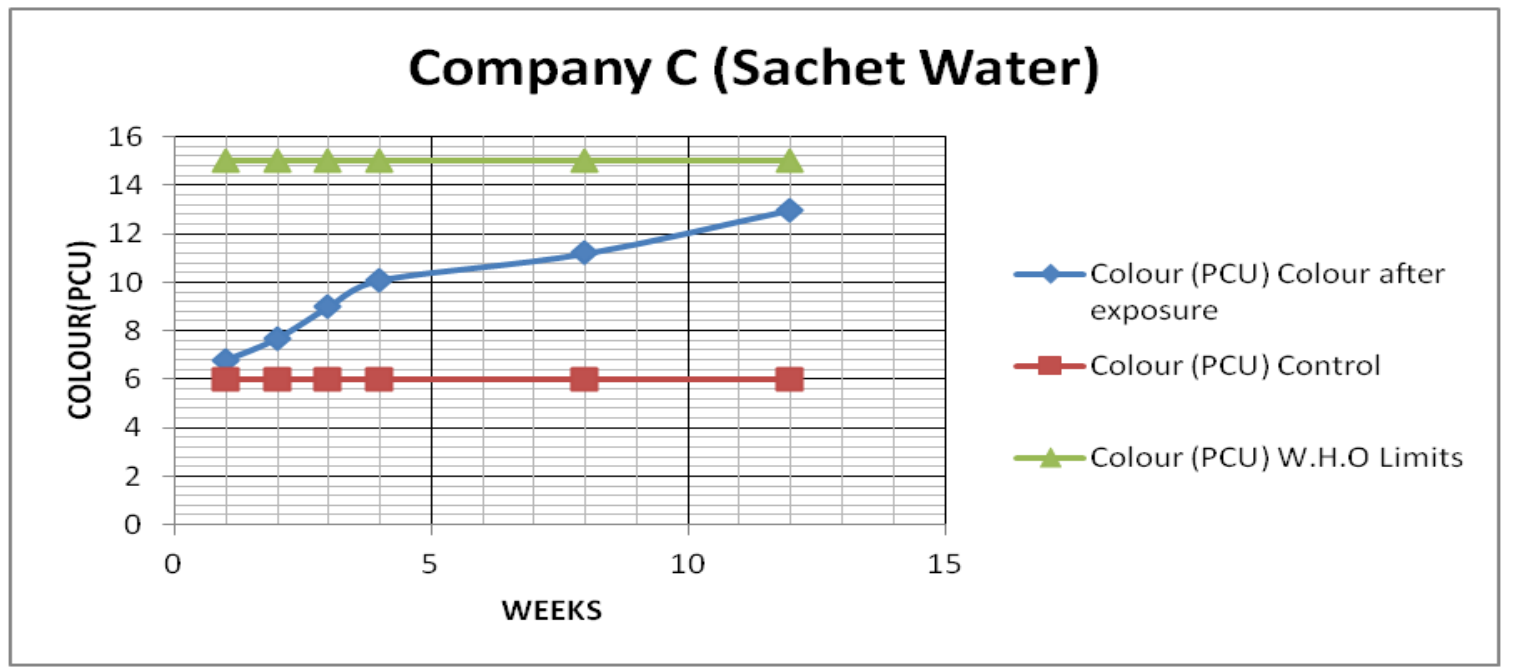

Figure 4.3c: Colour Analysis Result on sachet water for company C.

The results for colour as indicated in Figure 4.3a-c showed that there was a variation in colour, in the sachet brand of Company A : 6.3-13 PCU, Company B: 7.5-12.9 PCU and Company C: 6.8-13 PCU compared to the W.H.O Limits and Control (before exposure) of 5.7PCU, 7.1PCU and 6PCU respectively during the initial stage of sachet water shelf-life. Figure $4.3 \mathrm{a}$ shows a high colour value of $10.2 \mathrm{PCU}, 11.6 \mathrm{PCU}$ and $13 \mathrm{PCU}$ on the $4^{\text {th }}$, 8th and $12^{\text {th }}$ week (first three months) respectively, a line tending towards the W.H.O limit is observed in Figure 4.3a-c indicating a change in colour with time and condition of exposure especially on the $2^{\text {nd }}$ and $3^{\text {rd }}$ month; thereby supporting the claim that materials and metals are leached into the water sample as a result of effect of sun radiation on the packaging material. 
International Journal of Engineering Applied Sciences and Technology, 2021

Vol. 6, Issue 2, ISSN No. 2455-2143, Pages 192-208

Published Online June 2021 in IJEAST (http://www.ijeast.com)

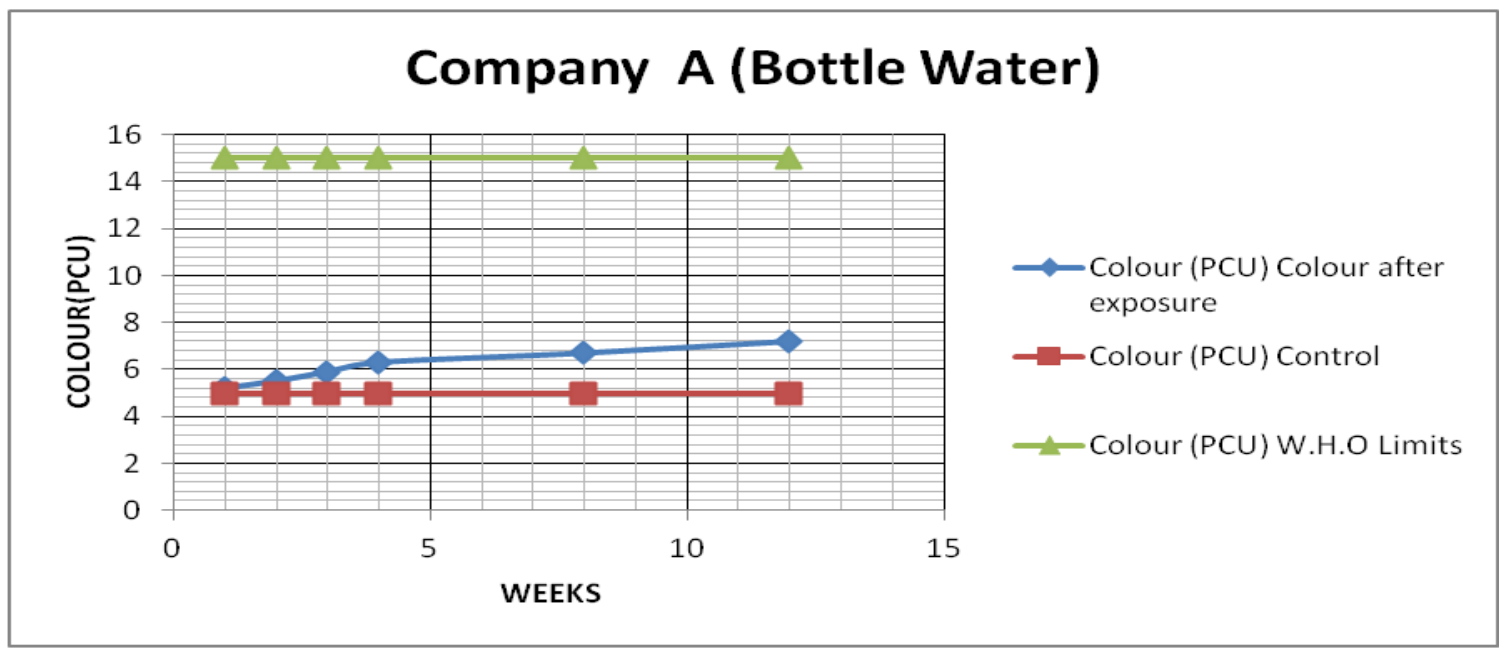

(PCU) - Platinum Cobalt Unit

Figure 4.3d: Colour Analysis Result on bottled water for company A.

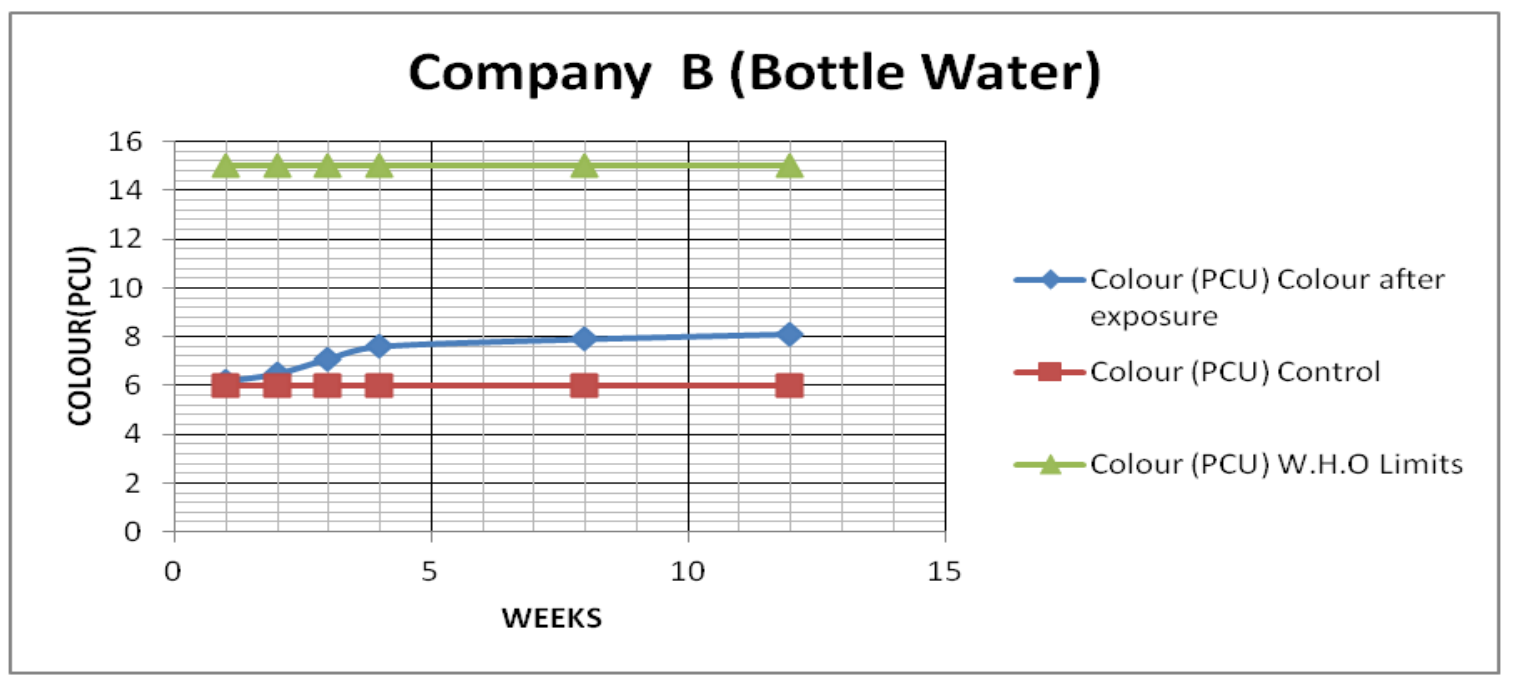

(PCU) - Platinum Cobalt Unit

Figure 4.3e: Colour Analysis Result on bottled water for company B. 


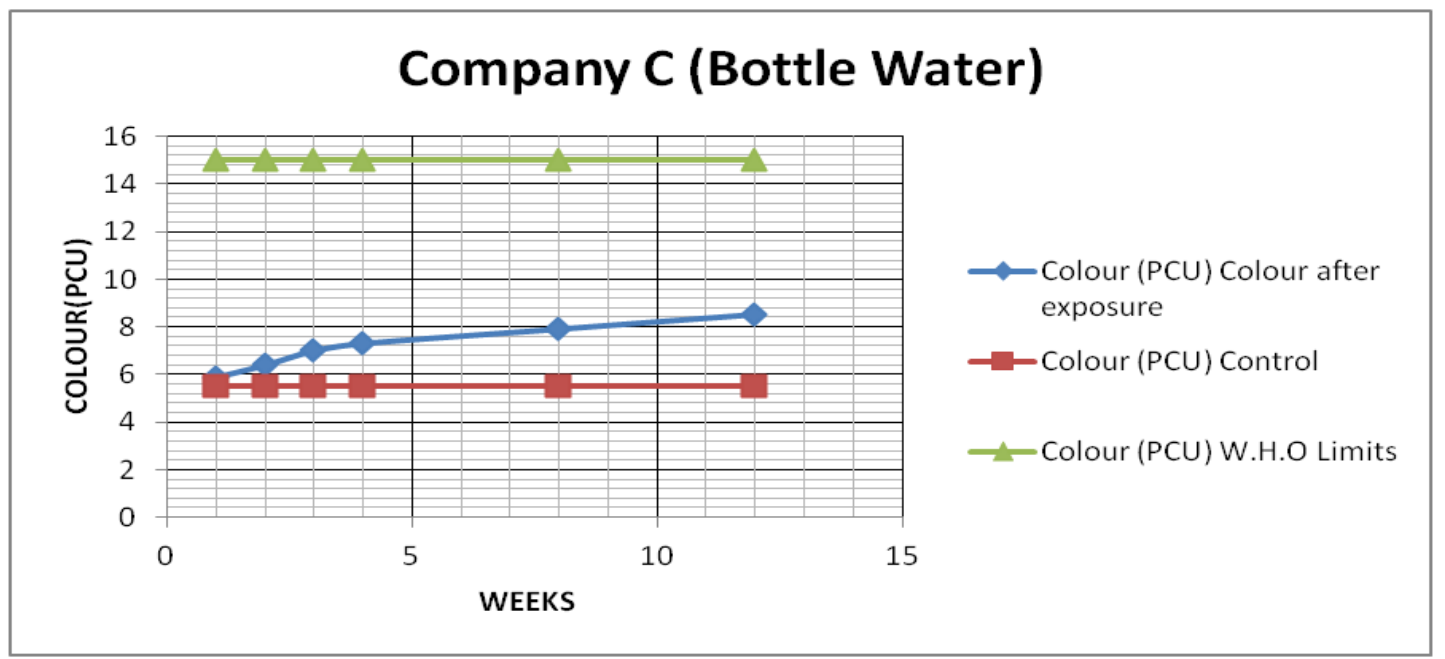

\section{(PCU) - Platinum Cobalt Unit}

Figure 4.3f: Colour Analysis Result on bottled water for company C.

The results for colour showed a range in value for Company A: 5.2-7.2 PCU, Company B: 6.2-8.1PCU and Company C: 5.9-8.5PCU after exposure. Figure 4.3d-f indicates a gradual change in colour in the various bottled packaged sample with time and condition of exposure through the period of study. A control (before exposure) of 5PCU, 6PCU and 5.5PCU for Company A, B and C respectively, were recorded.

\section{Odour}

Odour is recognized as a quality factor affecting acceptability of drinking water. Most organic and some inorganic chemicals contribute taste or odour.Consequently, growth of nuisance microorganisms is enhanced by warm water conditions and could lead to the development of unpleasant tastes and odours

Table 4.1a: observations obtained from analysis of odour in bottle water exposed to sun radiation

\begin{tabular}{|c|c|c|c|}
\hline \multirow[t]{2}{*}{ Weeks } & \multicolumn{2}{|c|}{ Odour } & \\
\hline & Company A & Company B & Company $\mathrm{C}$ \\
\hline 1 & NIL & NIL & NIL \\
\hline 2 & NIL & NIL & NIL \\
\hline 3 & NIL & NIL & NIL \\
\hline 4 & NIL & Polymeric & NIL \\
\hline 8 & Polymeric & Relatively pungent & Polymeric \\
\hline 12 & Polymeric & Relatively pungent & Polymeric \\
\hline
\end{tabular}

Table 4.1b: Results from analysis of odour in satchet water

Weeks Odour


International Journal of Engineering Applied Sciences and Technology, 2021

Vol. 6, Issue 2, ISSN No. 2455-2143, Pages 192-208

Published Online June 2021 in IJEAST (http://www.ijeast.com)

\begin{tabular}{llll}
\hline & Company A & Company B & Company C \\
$\mathbf{1}$ & Polymeric & Polymeric & Polymeric \\
$\mathbf{2}$ & Polymeric & Polymeric & Polymeric \\
$\mathbf{4}$ & Polymeric & Polymeric & Polymeric \\
$\mathbf{8}$ & Polymeric & Polymeric & Polymeric \\
$\mathbf{1 2}$ & Polymeric & Polymeric & Polymeric \\
\hline
\end{tabular}

Table 4.1a and 4.1b shows that through the period of study it was observed that the samples exposed maintained a consistency of a polymeric odour especially the sachet water samples, exceptions (relatively pungent odour) were noticed on the second and third month for company B's bottled water.

\section{Taste}

Many dissolved substances are undesirable in water. Dissolved minerals, gases and organic constituents may produce aesthetically displeasing colour, taste and odour. In assessing the quality of drinking-water, consumers rely principally upon their senses. The presence of sulphate in drinking water can also result in a noticeable taste; the lowest taste threshold concentration for sulphate is approximately $250 \mathrm{mg} / \mathrm{l}$, as the sodium salt. Concentrations above $5 \mathrm{mg} / \mathrm{l}$ may cause a bitter a stringent taste and opalescence in alkaline water.

Table 4.2a: Result from analysis of taste in bottled water.

\begin{tabular}{|c|c|c|c|}
\hline \multirow[t]{2}{*}{ Weeks } & \multicolumn{2}{|c|}{ Taste } & \\
\hline & Company A & Company B & Company C \\
\hline 1 & NIL & NIL & NIL \\
\hline 2 & NIL & NIL & NIL \\
\hline 3 & NIL & NIL & NIL \\
\hline 4 & Polymeric & NIL & Polymeric \\
\hline 8 & Polymeric & Polymeric & Polymeric \\
\hline 12 & Polymeric & Polymeric & Polymeric \\
\hline
\end{tabular}

Table 4.2b: Result from analysis of taste in sachet water.

\begin{tabular}{|l|l|l|l|}
\hline \multirow{2}{*}{ Weeks } & \multicolumn{2}{|c|}{ Taste } & Company C \\
\cline { 2 - 4 } & Company A & Company B & Polymeric \\
\hline $\mathbf{1}$ & Polymeric & Polymeric & \\
\hline
\end{tabular}


International Journal of Engineering Applied Sciences and Technology, 2021

Vol. 6, Issue 2, ISSN No. 2455-2143, Pages 192-208

Published Online June 2021 in IJEAST (http://www.ijeast.com)

\begin{tabular}{|l|l|l|l|}
\hline $\mathbf{2}$ & Polymeric & Polymeric & Polymeric \\
\hline $\mathbf{3}$ & Polymeric & Polymeric & Polymeric \\
\hline $\mathbf{4}$ & Polymeric & Polymeric & Polymeric \\
\hline $\mathbf{8}$ & Polymeric & Polymeric & Polymeric \\
\hline $\mathbf{1 2}$ & Polymeric & Polymeric & Polymeric \\
\hline
\end{tabular}

Through the period of study it was observed that sachet samples started experienced a change in taste after the first week of exposure up to the third month. The bottled samples had variation in taste after the first month; leaning towards the preference of bottled to sachet water.

\section{Microbiological Analysis}

Results of microbial quality of sachet and bottled water shows that, Coliforms,faecal streptococci,salmonella sp, vibrio sp,shigella sp,clostridia sp, yeast cells / moulds and algae were not detected in any of the brands before storage and after exposure under the various conditions. Company A, B and $\mathrm{C}$ has a total plate count of $1.0 \times 10^{1}, 0.3 \times 10^{1}$ and $1.5 \times 10^{1} \mathrm{cfu} / \mathrm{ml}$ respectively. General appearance in terms of colour, odor and turbidity is satisfactory and from the microbiology test result, there is no presence of faecal coliforms which leads to satisfactory results.

\section{CONCLUSION}

On the bases of this study, it can be concluded that the concentration levels of various physiochemical parameters in the studied packaged water types did not exceed the international guidelines for drinking water but variations of physiochemical properties were found when compared with the control (value before storage). Such variation can be attributed to the leaching of the compounds produced from the photodegradation of PET by sunlight. Due to the presence of organic and inorganic compounds in the water sample, residual chlorine underwent a depleting process while the result obtained for colour slightly increased, a slight variation was experienced in the $\mathrm{pH}$ of samples analysed while the taste and odour deteriorated with time (sachet water; after the first week of exposure while bottled water varied after the fourth week) giving off a relative polymeric assessment. The storage of packaged water in condition above $35^{\circ} \mathrm{C}$ or exposure to sunlight leads to acceleration of organic and inorganic compounds leaching from the packaging material to the content water especially that of sachet water. The study has shown that storage conditions of sachet water products present varying bacteriological qualities. Sachet water products when exposed to sunlight deteriorate faster than refrigerated ones due to solar radiation effect and inadequate chemical treatment. The deterioration was observed to have commenced from the fourth week of storage. Judging from the result, the effect of sun radiation was more on the sachet water when a comparison was drawn on its analysed result to that of the bottled water. Contamination was as a result of exposure to sun radiation and the effect on palatability of water is visible and noticed in odour and taste.

\section{REFERENCES}

[1] Alhassan, M. M. and Ujoh, F. (2012). Assessment of the Chemical Quality of Potable Water Sources in Abuja, Nigeria, British Journal of Applied Science \& Technology 2(2): 146- 172.

[2] Allen, H., Henderson, M. A. \& Hass, C. N. (1989). Chemical composition of bottled mineral water, Arch. of Environ. Health 44(2), 102-116.

[3] Benjamin, R., Chakrapani, B. K., Devashish, K., Nagarathna, A. V. \&Ramachandra, T. V. (1996). Fish mortality in Bangalore lakes, India. Electronic Green Journal, 6. Retrieved from http://egj.lib.uidaho.edu/egj06/ramachandra. $\underline{\text { html. }}$

[4] Chaidez, C., Rusin, P.,Naranjo, J. \& Gerba, C. P., (1999) Microbiological quality of water vending machines. International Journal of Environmental Health Research, 9, 197206.

[5] Cheabu, B. S., Ephraim N., \& James H., (2014) Sachet Water Quality in Obuasi, Ashanti Region, Ghana, Journal of Biology, 
Agriculture and Healthcare, Vol.4, No.5, Vol.4, 37-42.

[6] Clasen, T. F., and Cairncross, S., (2004). Editorial: household water management: refining the dominant paradigm. Tropical Medicine \& International Health 9, 187191.

[7] Dada, A. C. (2009). Sachet Water phenomenon in Nigeria: Assessment of the potential health impacts. African Journal of Microbiology Research, Vol.3 (1), 015-021, Available online http://www.academicjournals.org/ajmr. Food and Agricultural Organization. (1988). Agroclimatological data. Rome: Temedi Dell. Pg. $160-163$.

[8] Doria, M. F. (2006). Bottled Water versus tap water: understanding consumer's preferences. Journal of Water and Health, 04.2: pp.271-276.

[9] Gundry, S., Wright, J., Conroy, R., DuPreez, M., Genthe, B., Moyo, S., Mutisi, C., Ndamba, J., \&Potgieter, N. (2006) Contamination of drinking water between source and point-of-use in rural households of South Africa and Zimbabwe: implications for monitoring the Millennium Development Goal for water. Water Practice and Technology.

[10] Hunter, P. R. \& Barrell, R. A. (1999). Microbiological quality of drinking water from office water dispensers. Communicable Disease and Public Health/PHLS, 2, 67-68.

[11] Luksamijarulkul, C. (1994). The Bacteriological Examination of Water Supplies. London. Report on Public Health and Medical Subjects No. 71: 111-113.

[12] McSwane, D. Z., Oleckno, W. A. \& Eils, L. M. (1994) Drinking water quality concerns and water vending machines. Journal of Environmental Health, 56, 7-12.

[13] Mufeed, I. \& Batarseh, R. (2006). The Quality ofPotablewater Types in Jordan, Environmental Monitoring and Assessment, 117: 235-244.

[14] Musa, U., Aliyu, M.A., Sadiq, M. M., Mohammed, I. A., Manase, A. \& Mustapha, D. I. (2014). Quality Assessment of Sachet Water in Minna Metropolis of Niger State, Nigeria, Proceedings of 44th Annual
Conference, Exhibition of Nigerian Society of Chemical Engineers (NSChE), Nov. 2022nd, 2014, Owerri, Imo State.

[15] Mutsuga, M., Kawamura, Y., Sugita-Konishi, Y., Hara-Kudo, Y., Takatori, K., \& Tanamoto, K., (2006). Migration of formaldehyde and acetaldehyde into mineral water in polyethylene terephthalate (PET) bottles. Food Additives and Contaminants, 23(2): 212-218.

[16] Nsanze, H. \& Babarinde, Z. (1999). Microbiological Quality of Bottled Drinking Water in the UAE and the Effect of Storage at Different Temperatures. Environ. Int. 25(1), 53-57.

[17] Olaoye, O. A \& Onilude, A. A. (2009). Assessment of microbiological quality of sachet-packaged drinking water in Western Nigeria and its public health significance, Public Health 123 (2009) 729-734, doi:10.1016/j.puhe.2009.09.015.

[18] Onweluzo, J. C. \& Akuagbazie, C. A. (2010). Assessment Of The Quality Of Bottled And Sachet Water Sold In Nsukka Town, AgroScience Journal of Tropical Agriculture, Food, Environment and Extension, Volume 9, Number ,2, $104-110$.

[19] Page, B. D., Conacher, H. B., Salminen, J., Nixon, G. R., Riedel, G. \& Mori, B. (1993). Survey of bottled drinking water sold in Canada. Part 2.Selected volatile organic compounds. Journal of AOAC International, $76(1), 26-31$.

[20] Peter, S., Martin, K., Regula, M., Samuel, L. \& Martin, W., (2008).Does the reuse of PET bottles during solar water disinfection pose a health risk due to the migration of plasticisers and other chemicals into the water?, water research $42: 5054$ - 5060 .

[21] Pruss, A., Kay, D., Fewtrell, L. \& Bartram, J. (2002). Estimating the burden of disease from water, sanitation and hygiene at a global level. Environmental Health Perspective;110 (5): 537-42.

[22] Schillinger, J. \& Knorr, S. D. V. (2004). Drinking-water quality and issues associated with water vending machines in the city of Los Angeles. Journal of Environmental Health, 66, 25-31. 
[23] Uduma, A. U. (2014). Physicochemical analysis of the quality of sachet water consumed in kano metropolis. American Journal of Environment, Energy and Power Research 2: 1-10.

[24] World Health Organisation (1996). Guidelines for drinking water quality. 2nd Edition. Health criteria and other supporting information. Geneva, Switzerland.

[25] Wright, J., Gundry, S. \& Conroy, R., (2004). Household drinking water in developing countries: a systematic review of microbiological contamination between source and point-of-use. Tropical Medicine \& International Health 9, 106-117.

[26] Cristina, B. I, Xavier, D. \& Serge, E. (2009). Characterization of poly (ethylene terephthalate) used in commercial bottled water. Materials Science and Engineering 5, $1 ; 5-10$.

[27] Luksamijarukul, P., Pumswan, V. \& Pungchitton, S. (1994). Microbiological Quality of Drinking Water and using a water of Chao Phya River Community, Bangkok. South East Asia. Journal of Tropical Medicine and Public Health. 25 (4): 633637. 